\title{
Pyruvic Acid and Formic Acid Metabolism in Sarcina ventriculi and the Role of Ferredoxin
}

\author{
By M. P. STEPHENSON AND E. A. DAWES \\ Department of Biochemistry, University of Hull, \\ Kingston upon Hull, $H U 67 \mathrm{RX}$ \\ (Accepted for publication Io September 1971)
}

\begin{abstract}
SUMMAR Y
Sarcina ventriculi produced hydrogen, $\mathrm{CO}_{2}$ and acetyl phosphate from pyruvate by a clostridial-type thioclastic reaction which required coenzyme $A$ and ferredoxin for activity. Hydrogen production from formate did not require ferredoxin since crude formate hydrogenlyase preparations functioned when depleted of ferredoxin. With fractionated components of the enzymic system, ferredoxin or viologen dyes restored activity. No evidence for the presence of a coliform-type thioclastic reaction (pyruvate-formate lyase) was found. Reduction of NADP by hydrogen or formate was ferredoxin-dependent. Acetaldehyde and $\mathrm{CO}_{2}$ were produced from pyruvate by a yeast-type decarboxylase which required thiamine pyrophosphate and $\mathrm{Mg}^{2+}$ ions for activity. Extracellular $\mathrm{pH}$ influenced the pathways of pyruvate metabolism which were reflected by the molar growth yields for glucose; the thioclastic reaction was predominant at alkaline $\mathrm{pH}$.
\end{abstract}

\section{INTRODUCTION}

Sarcina ventriculi, a strict anaerobe capable of growth under extremely acidic conditions, ferments glucose via the Embden-Meyerhof pathway (Milhaud, Aubert \& van Niel, 1956). Smit (1930) and Kluyver (I93I) showed ethanol and carbon dioxide to be the major products of glucose catabolism and they concluded that a yeast-type alcoholic fermentation occurred. Subsequent experiments with washed bacterial suspensions (Milhaud et al. 1956) and with growing bacteria (Canale-Parola, I970) revealed the formation of large amounts of acetate and hydrogen, which suggested the operation of a coliform rather than a yeast-type fermentation. Bauchop \& Dawes (1959) and Arbuthnott, Bauchop \& Dawes (I960) indicated that the terminal fermentation mechanism of toluene-treated organisms consisted of two pathways of pyruvate catabolism, a yeast-type decarboxylase and a coliform-like thioclastic fission (pyruvate-formate lyase). The evidence for the latter route was incomplete, however, being inferred from the presence of an active formate hydrogenlyase system, which was subsequently investigated (Bauchop \& Dawes, 1968). We have now examined in greater detail the pathways of pyruvate catabolism in $S$. ventriculi and established the presence of a ferredoxin-dependent clostridial-type thioclastic reaction. A preliminary account of some of this work has appeared (Stephenson \& Dawes, 1970).

\section{METHODS}

Growth of organism. Sarcina ventriculi, isolated from soil as previously described (Bauchop \& Dawes, 1968), was maintained at $30^{\circ}$ by daily subculture in liquid medium which consisted of $\mathrm{I} \%(\mathrm{w} / \mathrm{v})$ yeast extract (Oxoid), $\mathrm{I} \%(\mathrm{w} / \mathrm{v})$ bacteriological peptone (Oxoid) and $2 \%(\mathrm{w} / \mathrm{v})$ $\mathrm{D}$-glucose. Organisms were grown without stirring in a 2 -litre boiling flask filled to the neck 
and under these conditions grew as a sediment on the bottom of the flask. All media were boiled and quickly cooled before inoculation to achieve anaerobic conditions.

Defined medium. The defined medium of Canale-Parola \& Wolfe (I960) was used which contained (g./IO0 ml.): glucose, 2.0; $\mathrm{Na}_{2} \mathrm{HPO}_{4}, 0.25 ; \mathrm{KH}_{2} \mathrm{PO}_{4}, 0.25 ; \mathrm{MgCl}_{2} .6 \mathrm{H}_{2} \mathrm{O}, 0.04$; $\mathrm{MnSO}_{4} .2 \mathrm{H}_{2} \mathrm{O}, 0.002$; $\mathrm{FeSO}_{4} .7 \mathrm{H}_{2} \mathrm{O}, 0.00 \mathrm{I}$; nicotinic acid, $2 \times 10^{-4}$; biotin, I $\times \mathrm{IO}^{-5}$; Larginine $\mathrm{HCl}$, L-valine, L-glutamic acid $\mathrm{HCl}$, L-serine, L-histidine $\mathrm{HCl}$, L-isoleucine, Lleucine, L-tyrosine, L-methionine, L-tryptophan, L-phenylalanine, $0.02 \mathrm{each}$. The final $\mathrm{pH}$ was $6 \cdot 5$ to $6 \cdot 8$.

Growth at constant $\mathrm{pH}$. Yeast extract $(30 \mathrm{~g}$.$) and peptone (30 \mathrm{~g}$.$) in 2.8$ litres of distilled water were autoclaved in a 5 -litre aspirator fitted with a rubber stopper holding a glass $\mathrm{pH}$ electrode and ports for alkali addition and gas exit. A tap fitted near the base allowed samples to be taken throughout growth. Immediately after autoclaving the solution was cooled to $30^{\circ}$ and sterile glucose solution $(60 \mathrm{~g}$. in $200 \mathrm{ml}$. water) added. An inoculum ( $\mathrm{I}$ to $5 \%, \mathrm{v} / \mathrm{v}$ ) of an actively gassing culture $(0.8 \mathrm{mg}$. dry wt $/ \mathrm{ml}$.) was added to the medium which was magnetically stirred. An E.I.L. Model 9IB controller (Electronic Instruments Ltd, Richmond, Surrey) maintained the $\mathrm{pH}$ to within $0 \cdot \mathrm{I}$ unit of the desired value by automatic addition of $8 \mathrm{~N}-\mathrm{NaOH}$.

Harvesting and preparation of bacterial extracts. All operations were performed anaerobically using $\mathrm{O}_{2}$-free $\mathrm{N}_{2}$ to displace air from flasks, tubes and solutions. Where possible solutions were boiled to expel $\mathrm{O}_{2}$. Bacteria were harvested in the exponential phase while vigorously gassing. The clear supernatant medium was siphoned off and the sediment of bacteria suspended in the small volume of medium remaining. This suspension was transferred to a centrifuge tube, fitted with a Suba-seal (Griffin \& George, Ltd, Manchester) and cooled to $0^{\circ}$. After centrifuging at $5000 \mathrm{~g}$ for $5 \mathrm{~min}$. the supernatant medium was withdrawn with a hypodermic syringe, the bacteria washed with 0.01 M-potassium phosphate, pH 6.8 , containing $30 \mathrm{mg} . \%(\mathrm{w} / \mathrm{v})$ cysteine hydrochloride and $10 \mathrm{mg} . \%$ (w/v) dithiothreitol, and suspended in a suitable volume of the same buffer. Bacteria were disrupted with a French press (French \& Milner, 1955) operated at 20,000 p.s.i. and the disrupted mass collected anaerobically. After centrifuging at $5000 \mathrm{~g}$ for Io min. the clear extract containing approximately $10 \mathrm{mg}$. protein $/ \mathrm{ml}$. was transferred by syringe to a fresh tube and stored under nitrogen at $0^{\circ}$.

Separation of formate dehydrogenase and hydrogenase enzymes by ammonium sulphate fractionation. Saturated $\left(\mathrm{NH}_{4}\right)_{2} \mathrm{SO}_{4}$ solution, made anaerobic by boiling and cooling under $\mathrm{O}_{2}$-free $\mathrm{N}_{2}$, was added to crude extract to give $40 \%$ saturation. After $20 \mathrm{~min}$. the precipitated protein was centrifuged at $5000 \mathrm{~g}$ for Io min., the supernatant transferred by syringe to a fresh tube and brought to $60 \%$ saturation by further addition of the saturated $\left(\mathrm{NH}_{4}\right)_{2} \mathrm{SO}_{4}$ solution. After $20 \mathrm{~min}$. the solution was centrifuged, the supernatant discarded and the precipitate dissolved in $0.0 \mathrm{I} \mathrm{M}$-potassium phosphate, $\mathrm{pH} 6.8$, containing $30 \mathrm{mg} . \%(\mathrm{w} / \mathrm{v})$ cysteine $\mathrm{HCl}$ and $\mathrm{I} 0 \mathrm{mg} . \%$ (w/v) dithiothreitol at a concentration of approx. Io mg. protein $/ \mathrm{ml}$. All operations were performed anaerobically at $0^{\circ}$.

Preparation of ferredoxin-free extract. Crude extract $(3 \mathrm{ml}$.) was placed on a DEAEcellulose column $(\mathrm{I} \mathrm{cm} . \times 5 \mathrm{~cm}$.) and eluted with distilled water. The ferredoxin remained adsorbed at the top of the column as a brown band and the eluate constituted the ferredoxinfree fraction. Anaerobic precautions were taken throughout.

Purification of ferredoxin. The method was modified from that of Mayhew (1966). The DEAE-cellulose column containing the adsorbed ferredoxin was washed with distilled water and then with $0.25 \mathrm{M}$-tris- $\mathrm{HCl}, \mathrm{pH} 8.0$, which eluted a pink and then a yellow band. The column was washed with $0.6 \mathrm{M}$-tris- $\mathrm{HCl}$ buffer, $\mathrm{pH} 8 \cdot 0$, which caused the brown ferredoxin 
band to move slowly down the column. When within I $\mathrm{cm}$. of the bottom, the band was eluted as a concentrated solution with I $\mathrm{M}$-tris- $\mathrm{HCl}$ buffer, $\mathrm{pH} 8 \cdot 0$, and then dialysed against distilled water. Further purification was achieved by ammonium sulphate fractionation and collection of the $60 \%$ to $90 \%$ saturated fraction.

Preparation of coenzyme A-depleted extract. Crude extract ( $3 \mathrm{ml}$.) was placed on a chromatographic column $(\mathrm{I} \mathrm{cm} . \times 5 \mathrm{~cm}$.) of Dowex-I-Cl resin $(20$ to $50 \mathrm{mesh})$ and eluted with distilled water. The first $50 \%$ of the eluted protein was collected and used as the coenzyme A-free extract. Anaerobic precautions were taken except when studying pyruvate decarboxylase activity.

Resolution of pyruvate decarboxylase. The method of Morey \& Juni (1968) for yeast was used.

Isotopic exchange experiments. These were conducted in Warburg flasks under an atmosphere of $\mathrm{N}_{2}$ at $30^{\circ}$. After incubation the reaction was terminated by the addition of $\mathrm{I} \mathrm{ml}$. $8 \mathrm{~N}-\mathrm{H}_{2} \mathrm{SO}_{4}$. Distilled water $(4 \mathrm{ml}$.) was then added and the precipitated protein centrifuged. The supernatant was transferred to a fresh tube and $50 \mu$ moles 2,4-dinitrophenylhydrazine in $0.5 \mathrm{ml} . \mathrm{I} 8 \mathrm{~N}-\mathrm{H}_{2} \mathrm{SO}_{4}$ added. The pyruvate derivative was collected by filtration, washed with $2 \times 10 \mathrm{ml}$. distilled water, dried at $50^{\circ}$ and dissolved in ethyl acetate. Samples were plated on nickel planchets (area $4.9 \mathrm{~cm}^{2}$ ) and the radioactivity measured with a NuclearChicago gas-flow Geiger counter. Corrections for background and self-absorption were applied.

Synthesis of desulphocoenzyme A. The method of Chase, Middleton \& Tubbs (1966) was used.

Chemical determinations. Glucose was determined with hexokinase/glucose 6-phosphate dehydrogenase (Boehringer test combination TGAB I 593I). Formate was determined by the method of Barker \& Somers (1966) and lactate with lactate dehydrogenase by the method of Hohorst (1963). Acetaldehyde was determined with alcohol dehydrogenase; and acetyl phosphate by the method of Lipmann \& Tuttle (1945). Pyruvate was determined by the method of Friedemann \& Haugen (1943). For acetate determinations the growth medium was deproteinized by the method of Somogyi as described by Neish (1952) and a suitable volume steam-distilled at $\mathrm{pH} 2 \cdot 8$ to $3 \cdot 0$. The distillate was titrated with $\mathrm{O} \cdot \mathrm{I} \mathrm{N}-\mathrm{NaOH}$ using thymol blue as indicator. Formic, lactic and pyruvic acids were not detected in any of the media analysed and therefore did not interfere with the acetate determination. Analyses were always carried out on samples taken immediately after inoculation to establish the base line for each experiment. Protein was determined by the biuret method of Gornall, Bardawill \& David (1949).

Dry weight determinations. Washed organisms from a known volume of medium were dried at $100^{\circ}$ to constant weight in tared glass vials.

Oxygen-free nitrogen. A glass column $(2 \mathrm{~cm} . \times 30 \mathrm{~cm}$.) filled with copper metal chippings heated to $360^{\circ}$ was used to remove the final traces of oxygen from commercial 'oxygen-free' nitrogen (British Oxygen Company Ltd, London, S.E. Io).

Sources of chemicals. Chemicals, wherever possible, were of analytical reagent grade and obtained from British Drug Houses Ltd, Poole, Dorset, or Hopkin \& Williams Ltd, Chadwell Heath, Essex. Enzymes, coenzyme A and ATP were obtained either from Boehringer Corporation (London) Ltd, or Sigma Ltd, London. Radiochemicals were obtained from the Radiochemical Centre, Amersham, Buckinghamshire. 


\section{RESULTS}

\section{Pyruvate decarboxylase}

Crude extracts of Sarcina ventriculi converted pyruvate to acetaldehyde and $\mathrm{CO}_{2}$, in either the presence or absence of $\mathrm{O}_{2}$, with a pH optimum of $5 \cdot 6$ (Fig. I). The yield of acetaldehyde obtained anaerobically depended upon the relative activities of the decarboxylase and thioclastic enzymes which were influenced differently by $\mathrm{pH}$ (Fig. I). The high yield of acetaldehyde (0.99 mole/mole pyruvate) obtained at $\mathrm{pH} 5.0$ decreased to 0.60 at $\mathrm{pH} 6.0$ and $0.2 \mathrm{I}$ at $\mathrm{pH} 7 \cdot 0$ as the activity of the thioclastic enzyme increased.

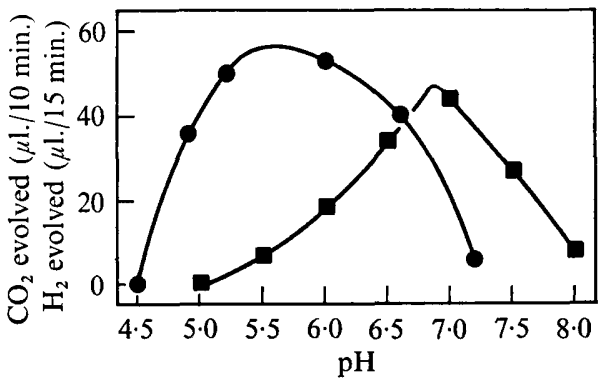

Fig. I

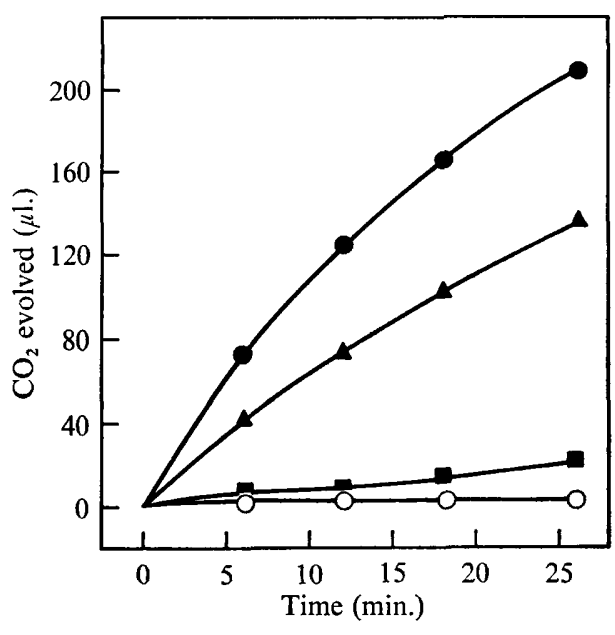

Fig. 2

Fig. I. Effect of pH on pyruvate decarboxylation and on hydrogen production by extracts of Sarcina ventriculi. For pyruvate decarboxylase (O) Warburg flasks contained: $2 \cdot 3 \mathrm{ml} .0 \cdot 2 \mathrm{M}-\mathrm{Na}_{2} \mathrm{HPO}_{4} /$ $0 . \mathrm{I}$ M-citric acid buffer at the required $\mathrm{pH} ; 30 \mu$ moles pyruvate (side arm); $2 . \mathrm{I} \mathrm{mg}$. bacterial protein; total volume $2.8 \mathrm{ml}$; $0.2 \mathrm{ml} .3 \mathrm{~N}_{2} \mathrm{H}_{2} \mathrm{SO}_{4}$ in the second side arm; atmosphere air; temperature $30^{\circ}$. For hydrogen production (ש) Warburg flasks contained: $2 \mathrm{ml} .0 .2 \mathrm{M}-\mathrm{Na}_{2} \mathrm{HPO}_{4} / \mathrm{O} \cdot \mathrm{I} \mathrm{M}$-citric acid buffer at the required $\mathrm{pH} ; 40 \mu$ moles pyruvate (side arm); $1 \cdot 9 \mathrm{mg}$. bacterial protein; total volume $2.4 \mathrm{ml}$; $0.15 \mathrm{ml} .20 \%$ (w/v) $\mathrm{KOH}$ (centre well); atmosphere $\mathrm{N}_{2}$, temperature $30^{\circ}$.

Fig. 2. Resolution of pyruvate decarboxylase. Extract $(4.5 \mathrm{ml}$.) containing $75.6 \mathrm{mg}$. protein was resolved and the final precipitate dissolved in 0.01 M-potassium phosphate, $\mathrm{pH} 6.0$, to a volume of $5.5 \mathrm{ml}$. All Warburg flasks contained: $170 \mu$ moles potassium phosphate and $40 \mu$ moles pyruvate (side arm). As appropriate, additions were made of $0.2 \mathrm{ml}$. crude extract protein (3.3 mg.) or $0.2 \mathrm{ml}$. resolved enzyme solution; $0.5 \mu$ mole $\mathrm{MgSO}_{4} ; 0.019 \mu$ mole thiamine pyrophosphate. Total volume $2.3 \mathrm{ml}$; $\mathrm{pH} 6.0$; temperature $30^{\circ}$; atmosphere air. 0 , Crude extract; $O$, resolved extract $+\mathrm{MgSO}_{4}$; $\boldsymbol{\square}$, resolved extract + thiamine pyrophosphate; $\Delta$, resolved extract $+\mathbf{M g S O}_{4}+$ thiamine pyrophosphate.

The reaction was sensitive to the same inhibitors as a yeast-type decarboxylase (King \& Cheldelin, 1954) giving results (Table I) similar to those obtained with toluene-treated cells by Bauchop \& Dawes (I959).

Resolution of the enzyme by the method of Morey \& Juni (1968) showed that, like yeast, only thiamine pyrophosphate and $\mathrm{Mg}^{2+}$ ions were required for activity (Fig. 2). Removal of coenzyme A from crude extracts with Dowex-I-Cl resin was without effect.

The crude enzyme was not specific for pyruvate and decarboxylated 2-oxobutyrate and 2-oxoisovalerate with relative rates of $\mathrm{I} \cdot 60$ and 0.37 respectively (pyruvate $=\mathrm{I}$ ) at $\mathrm{pH} 6 \cdot 0$. 


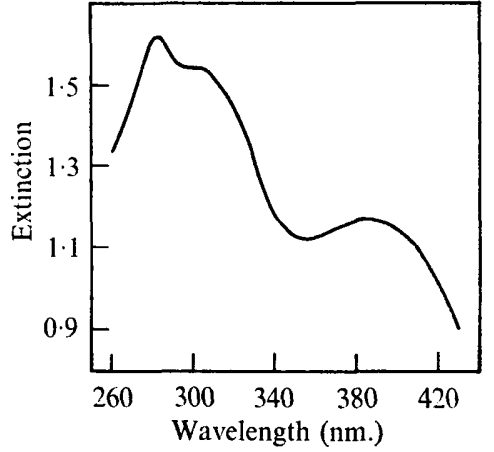

Fig. 3

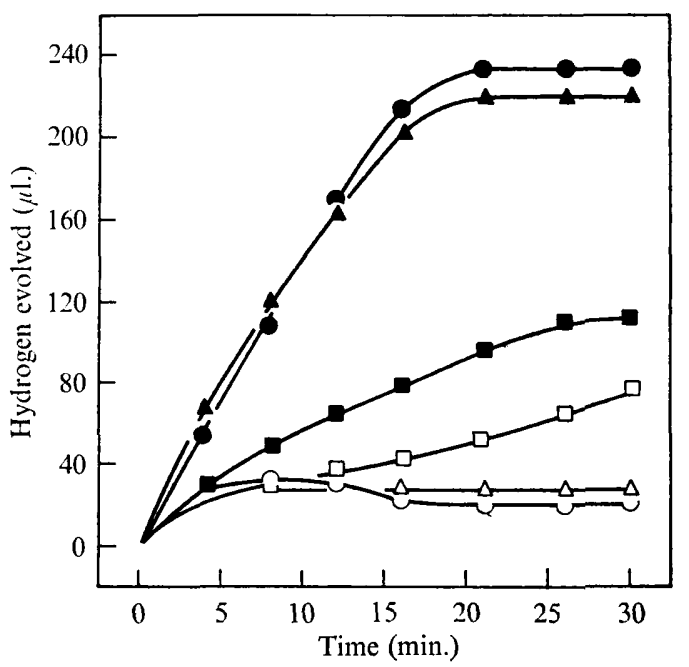

Fig. 4

Fig. 3. Absorption spectrum of oxidized Sarcina ventriculi ferredoxin. The ferredoxin was dissolved in distilled water $(0.18 \mathrm{mg}$. protein $/ \mathrm{ml}$.) and the absorption spectrum measured with a Unicam SP 800 spectrophotometer.

Fig. 4. Hydrogen production from pyruvate by untreated and DEAE-cellulose-treated extract of Sarcina ventriculi. Warburg flasks contained: $120 \mu$ moles potassium phosphate; $20 \mu$ moles pyruvate (side arm); $3 \cdot 1 \mathrm{mg}$. DEAE-cellulose-treated protein, except ( $\square$ ) which contained $5 \cdot 2 \mathrm{mg}$. untreated protein; $0.1 \mathrm{ml}$. of $20 \%(\mathrm{w} / \mathrm{v}) \mathrm{KOH}$ (centre well). Where appropriate, flasks contained $0.36 \mu \mathrm{mole}$ coenzyme A; $0.37 \mathrm{mg}$. ferredoxin; $2 \mu$ moles methyl viologen. Total volume $2.25 \mathrm{ml}$; $\mathrm{pH} 7 \cdot 0$; temperature $30^{\circ}$; atmosphere $\mathrm{N}_{2} . \ominus$, Coenzyme $\mathrm{A}+$ methyl viologen; $\boldsymbol{\Delta}$, coenzyme $\mathrm{A}+$ ferredoxin; $\square$, ferredoxin; $\triangle$, coenzyme $A ; O$, no addition.

\section{Table I. Inhibition of pyruvate decarboxylase}

Warburg flasks contained: I $80 \mu$ moles potassium phosphate; $20 \mu$ moles pyruvate; $2 \cdot 1$ mg. crude extract protein; inhibitors at the concentrations indicated; total volume $2.35 \mathrm{ml}$; $\mathrm{pH} 5 \cdot 8$; atmosphere air; temperature $30^{\circ}$. The initial rate of the reaction in the absence of inhibitor was $186 \mu 1 . / \mathrm{h} . /$ mg. protein.

\begin{tabular}{lcc}
\multicolumn{1}{c}{ Inhibitor } & $\begin{array}{c}\text { Inhibitor } \\
\text { concentration } \\
(\mathrm{mM})\end{array}$ & Inhibition (\%) \\
$\mathrm{CuSO}_{4}$ & 0.13 & 96 \\
$\mathrm{Hg}_{4}\left(\mathrm{NO}_{3}\right)_{2}$ & 0.13 & 98 \\
$\mathrm{AgNO}_{3}$ & 0.15 & 94 \\
& $1 \cdot 50$ & 98 \\
$p$-Chloromercuribenzoate & 0.13 & 98
\end{tabular}

\section{Hydrogen production by extracts of Sarcina ventriculi}

Stoicheiometry. Extracts of Sarcina ventriculi prepared and used with anaerobic precautions converted pyruvate to (mole/mole pyruvate at $\mathrm{pH} 6 \cdot 0$ ): hydrogen, 0.39 ; carbon dioxide, 0.99 ; acetyl phosphate, 0.38 ; and acetaldehyde, 0.60 . With formate, equimolar amounts of hydrogen and carbon dioxide were produced. Both hydrogen-producing reactions were strongly inhibited by oxygen.

Presence of ferredoxin. The product from DEAE-cellulose chromatography and subsequent purification was spectrally similar to other bacterial ferredoxins with absorption 


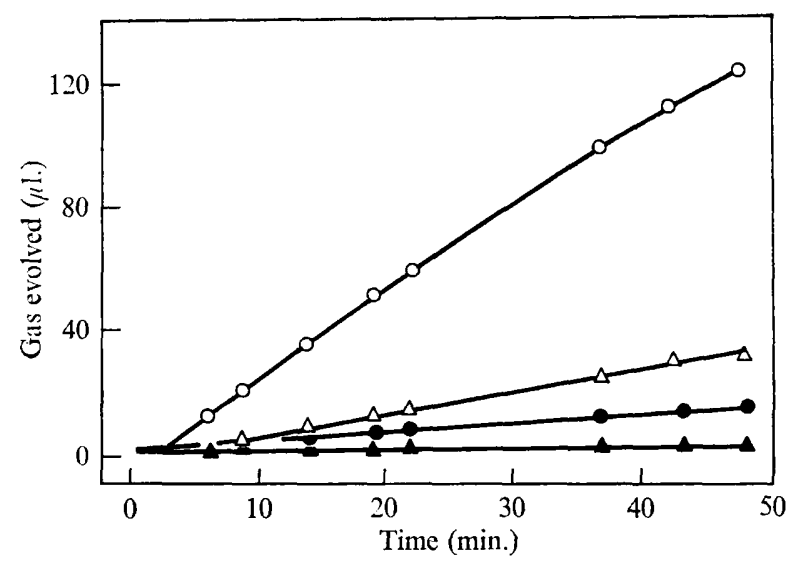

Fig. 5. Hydrogen and $\mathrm{CO}_{2}$ production from formate by ammonium sulphate fractionated extract. Warburg flasks contained: $200 \mu$ moles potassium phosphate; $20 \mu$ moles formate (side arm); $3.8 \mathrm{mg}$. protein; and, as appropriate, $0.6 \mathrm{mg}$. Sarcina ferredoxin, and $0.05 \mathrm{ml} .20 \%(\mathrm{w} / \mathrm{v}) \mathrm{KOH}$ (centre well). Total volume $1 \cdot 25 \mathrm{ml}$; $\mathrm{pH} 6 . \mathrm{I}$; temperature $30^{\circ}$; atmosphere $\mathrm{N}_{2}$. $\mathrm{CO}_{2}$ evolution in the presence $(O)$ and absence $(\Theta)$ of ferredoxin. $H_{2}$ evolution in the presence $(\triangle)$ and absence $(\Delta)$ of ferredoxin.

maxima at 282 and $390 \mathrm{~nm}$. (Fig. 3). Sarcina ferredoxin could replace Peptostreptococcus elsdenii ferredoxin in the reduction of sulphite by hydrogen in extracts of that organism.

Role of ferredoxin in hydrogen production from pyruvate. When ferredoxin was removed from active extracts, hydrogen production from pyruvate was abolished. Activity was restored by the addition of coenzyme A together with either Sarcina ferredoxin or methyl viologen (Fig. 4); the thioclastic reaction thus resembles that found in some clostridia (Mortenson, Valentine \& Carnahan, 1962).

Effect of $p H$. The optimum $\mathrm{pH}$ for evolution of hydrogen from pyruvate was $6 \cdot 8$ (Fig. $\mathrm{I}$ ).

Role of ferredoxin in hydrogen production from formate. When extracts of Sarcina ventriculi which evolved equimolar amounts of $\mathrm{H}_{2}$ and $\mathrm{CO}_{2}$ from formate were treated anaerobically with DEAE-cellulose to remove the ferredoxin, no activity was lost.

Although the possibility exists that in crude extracts some ferredoxin may remain bound to a component of the formate hydrogenlyase system after DEAE-cellulose treatment, this seems unlikely since the treated extracts were unable to replace Peptostreptococcus elsdenii ferredoxin in the reduction of sulphite by hydrogen in extracts of that organism. Furthermore, the activities of all other ferredoxin-requiring reactions studied with Sarcina ventriculi extracts were abolished by DEAE-cellulose treatment whereas formate hydrogenlyase activity was unaffected.

To test for a possible role of ferredoxin in the absence of other electron carriers, a method for the isolation of the enzymes of the formate hydrogenlyase system was devised. Anaerobic fractionation of crude extracts with $\left(\mathrm{NH}_{4}\right)_{2} \mathrm{SO}_{4}$ yielded a fraction between $40 \%$ and $60 \%$ saturation which contained formate dehydrogenase and hydrogenase activities but which lacked the necessary electron carrier(s) for the overall formate hydrogenlyase system to operate. Activity was restored by the addition of either Sarcina ferredoxin (Fig. 5), benzyl viologen or methyl viologen.

Specific activity of formate hydrogenlyase. During growth at $\mathrm{pH} 6.0$ and 7.6 in complex medium typical specific activities were 96 and $72 \mu \mathrm{l} . \mathrm{H}_{2} / \mathrm{mg}$. dry wt $/ \mathrm{h}$. respectively. During growth in defined medium (initial $\mathrm{pH} 6.6$ ) a value of $108 \mu \mathrm{l} . \mathrm{H}_{2} / \mathrm{mg}$. dry wt $/ \mathrm{h}$. was obtained. 


\section{$\mathrm{CO}_{2}$-pyruvate and $\mathrm{HCOOH}$-pyruvate exchange reactions}

Effect of coenzyme $A$. After extracts were treated with Dowex-I-Cl resin to remove coenzyme A, stimulation of the exchange reactions was observed on subsequent addition of catalytic amounts of the coenzyme (Table 2).

Effect of desulphocoenzyme A. The coenzyme A analogue desulphocoenzyme A strongly inhibited both exchange reactions in coenzyme A-depleted extracts (Table 3); the inhibition was less marked in untreated extracts because of competition from the coenzyme A present.

Effect of an unlabelled pool of $\mathrm{CO}_{2}$ on $\mathrm{HCOOH}$-pyruvate exchange. When a pool of unlabelled $\mathrm{CO}_{2}$ was added no incorporation occurred (Table $2 b$ ).

Table 2. (a) Effect of coenzyme $\mathrm{A}$ on $\mathrm{CO}_{2}$-pyruvate and HCOOH-pyruvate exchange

Warburg flasks contained: I $50 \mu$ moles potassium phosphate; $100 \mu$ moles pyruvate; I00 $\mu$ moles $\mathrm{H}^{14} \mathrm{COOH}, \mathrm{I}_{640}$ counts/min./ $/$ mole (formate exchange); $100 \mu$ moles $\mathrm{NaH}^{14} \mathrm{CO}_{3}, 559$ c.p.m./ $\mu$ mole $\left(\mathrm{CO}_{2}\right.$ exchange); $0.1 \mathrm{ml}$. of a reducing complex of $0.01 \mathrm{M}-\mathrm{FeSO}_{4}+0.03 \mathrm{M}-2,3$-dimercaptopropanol; I.9 mg. protein; and, as appropriate, $0.08 \mu$ mole coenzyme A; total volume $2.2 \mathrm{ml}$.; $\mathrm{pH} \mathrm{7.2}$; $30 \mathrm{~min}$. incubation. The values in parentheses represent percentage incorporation of radioactivity.

$\begin{array}{lcc}\text { Addition } & \begin{array}{c}\text { Specific activity of pyruvate } \\ 2,4 \text {-dinitrophenylhydrazone } \\ \text { (c.p.m. } / \mu \text { mole) }\end{array} \\ \text { None } & \mathrm{CO}_{2} \text {-pyruvate } & \text { HCOOH-pyruvate } \\ \text { Coenzyme A } & 50(18) & 17(2) \\ 90(32) & 27(3)\end{array}$

(b) Effect of a pool of unlabelled $\mathrm{CO}_{2}$ on $\mathrm{HCOOH}$-pyruvate exchange

Warburg flasks contained: $250 \mu$ moles potassium phosphate; $100 \mu$ moles pyruvate; $100 \mu$ moles $\mathrm{H}^{14} \mathrm{COOH}$, 1640 c.p.m. $/ \mu$ mole; $0.2 \mathrm{ml}$. of $0.01 \mathrm{M}-\mathrm{FeSO}_{4}+0.03 \mathrm{M}-2,3$-dimercaptopropanol; $2.8 \mathrm{mg}$. protein; and, where appropriate, $500 \mu$ moles $\mathrm{NaHCO}_{3}$ brought to $\mathrm{pH} 7.2$ with $\mathrm{KH}_{2} \mathrm{PO}_{4}$;

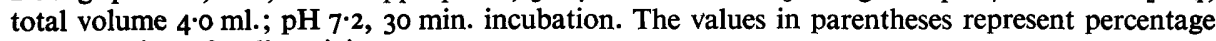
incorporation of radioactivity.

$\begin{array}{lc} & \begin{array}{c}\text { Specific activity of pyruvate } \\ \text { 2,4-dinitrophenylhydrazone } \\ \text { (c.p.m. } / \mu \text { mole) }\end{array} \\ \mathrm{NaHCO}_{3} \text { absent } & \text { I90 (23) } \\ \mathrm{NaHCO}_{3} \text { present } & \circ(0)\end{array}$

Table 3. Effect of desulphocoenzyme $\mathrm{A}$ on $\mathrm{CO}_{2}$-pyruvate and $\mathrm{HCOOH}$-pyruvate exchange by Dowex-I-Cl treated and untreated extracts

Warburg flasks contained: I00 $\mu$ moles potassium phosphate, I00 $\mu$ moles pyruvate; I00 $\mu$ moles $\mathrm{H}^{14} \mathrm{COOH}$, 1640 c.p.m. $/ \mu$ mole (formate exchange) or $100 \mu$ moles $\mathrm{NaH}^{14} \mathrm{CO}_{3}$, I000 c.p.m./ $\mu$ mole $\left(\mathrm{CO}_{2}\right.$ exchange); $0.2 \mathrm{ml}$. of $0.01 \mathrm{M}-\mathrm{FeSO}_{4}+0.03 \mathrm{M}-2,3$-dimercaptopropanol; and, as appropriate, $2 \mathrm{mg}$. Dowex- $\mathrm{I}-\mathrm{Cl}$ treated extract protein or $3.2 \mathrm{mg}$. untreated extract protein; and $0.32 \mu$ mole desulphocoenzyme A; total volume $2 \cdot 2 \mathrm{ml}$.; $\mathrm{pH} 7 \cdot 2 ; 25 \mathrm{~min}$. incubation. Values in parentheses represent the percentage incorporation of radioactivity.

Specific activity of pyruvate 2,4-dinitrophenylhydrazone (c.p.m./ $/ \mu$ mole)

Extract Addition

Dowex-I-Cl

treated

Untreated

None

Desulphocoenzyme A

None

Desulphocoenzyme A

$\begin{array}{cc}\mathrm{CO}_{2} \text {-pyruvate } & \text { HCOOH-pyruvate } \\ 300(60) & 70(9) \\ \text { I } 3(3) & 6(<\mathrm{I}) \\ 430(86) & 260(32) \\ \text { I } 74(35) & 29(4) \\ & \text { M I C } 69\end{array}$




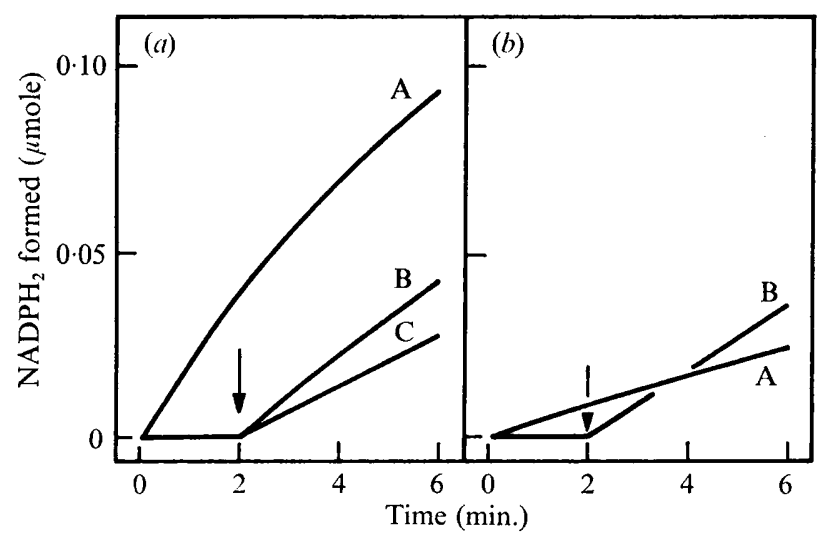

Fig. 6. Reduction of NADP by hydrogen or formate.

(a) Cuvettes contained: $\mathrm{I} \cdot 5$ mmoles potassium phosphate; $20 \mu$ moles formate; $0.85 \mu$ mole NADP; $2.5 \mathrm{mg}$. untreated extract protein (A) or $2.4 \mathrm{mg}$. DEAE-cellulose-treated extract protein; total volume $2.75 \mathrm{ml}$.; $\mathrm{pH} 8.0$; atmosphere $\mathrm{N}_{2}$; temperature $25^{\circ}$. At the arrow, $0.24 \mathrm{mg}$. ferredoxin (B) and $0 \cdot 2 \mu$ mole benzyl viologen (C) were added.

(b) Cuvettes contained: $1 \cdot 5$ mmoles potassium phosphate; $0.85 \mu$ mole NADP; $3.8 \mathrm{mg}$. untreated extract protein (A); $3.6 \mathrm{mg}$. DEAE-cellulose treated extract protein (B); total volume $2.75 \mathrm{ml}$; $\mathrm{pH} 8 \cdot 0$; atmosphere $\mathrm{H}_{2}$; temperature $25^{\circ}$. At the arrow, $0.24 \mathrm{mg}$. ferredoxin was added.

Specificity. No incorporation of $\mathrm{CO}_{2}$ or $\mathrm{HCOOH}$ into either 2-oxobutyrate, 2-oxovalerate, 2-oxoisovalerate or 2-oxoglutarate was observed.

\section{Reduction of NADP by hydrogen or formate}

Extracts reduced NADP anaerobically with hydrogen or formate but extracts which had been treated anaerobically with DEAE-cellulose to remove ferredoxin were inactive unless supplemented with Sarcina ferredoxin or benzyl viologen (Fig. $6 a$ and $b$ ). The reaction, which was specific for NADP, was observed only under anaerobic conditions because of the sensitivity of the hydrogenase enzyme to oxygen and the presence of an NADPH-oxidase.

\section{Acetaldehyde dehydrogenase}

Acetaldehyde dehydrogenase activity was demonstrated in extracts of Sarcina ventriculi with acetyl coenzyme A as the substrate (Fig. 7a). The enzyme was specific for NADH.

Sarcina ventriculi possesses the enzymes phosphotransacetylase and acetokinase (CanaleParola, 196I) and the ability of acetate and acetyl phosphate to oxidize NADH via these enzymes was tested. With both substrates NADH oxidation occurred with crude extracts (Fig. $7 b$ and $c$ ) and in the case of acetyl phosphate was coenzyme A-dependent (Fig. $7 d$ ).

\section{Effect of controlled extracellular $p H$ during growth on the pathways of pyruvate metabolism}

In the observed absence of lactate formation, acetate production from glucose can be used as an index of the operation of the thioclastic pathway; if all the pyruvate were metabolized via the thioclastic route the theoretical maximum yield would be I mole acetate/mole glucose fermented since acetate production is accompanied by an equivalent formation of ethanol. The influence of $\mathrm{pH}$ of the growth medium on the pathways of pyruvate metabolism is thus 


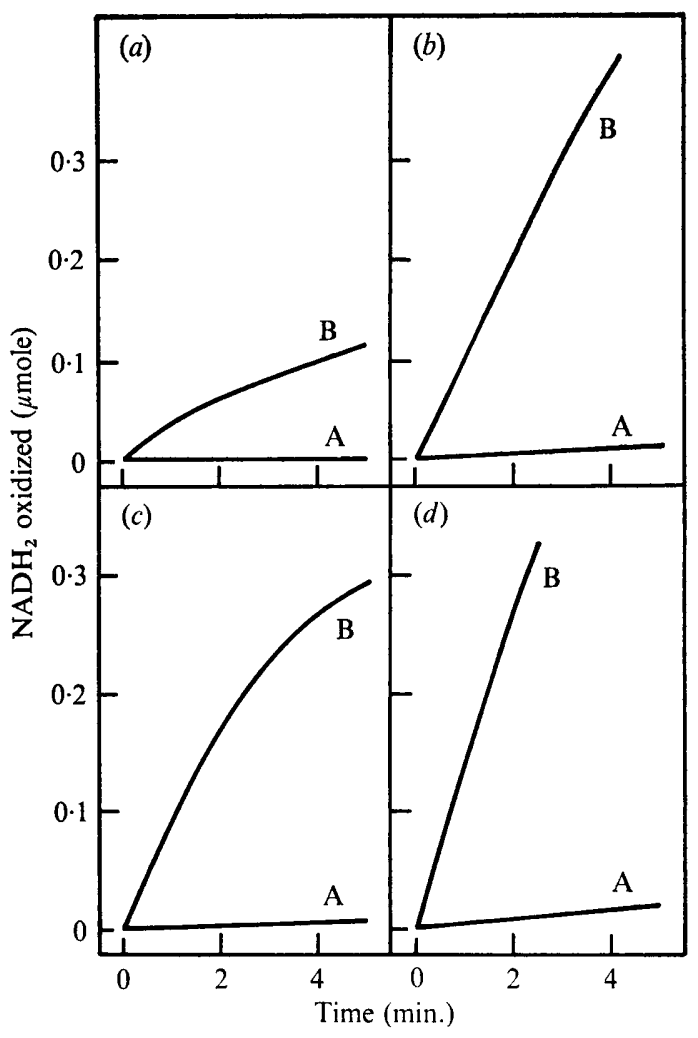

Fig. 7. Acetaldehyde dehydrogenase activity in extracts of Sarcina ventriculi. All cuvettes contained : $200 \mu$ moles potassium phosphate except $(b)$ which contained $20 \mu$ moles; I I $\mu$ moles dithiothreitol; $0.6 \mu$ mole $\mathrm{NADH}_{2}$ except $(b)$ which contained $2.14 \mu$ moles; other additions as indicated.

(a) I. $2 \mu$ moles acetyl coenzyme A (B); $0.9 \mathrm{mg}$. crude extract protein; total volume $2.6 \mathrm{ml}$.

(b) $5.8 \mu$ moles ATP; $200 \mu$ moles acetate (B); $2.7 \mathrm{mg}$. crude extract protein; total volume $3.0 \mathrm{ml}$

(c) $0.9 \mu$ mole acetyl phosphate (B); $3.3 \mathrm{mg}$. crude extract protein; total volume $2.6 \mathrm{ml}$.

(d) $0.9 \mu$ mole acetyl phosphate; $0.23 \mu$ mole coenzyme A (B); $2.8 \mathrm{mg}$. Dowex-I-Cl resin-treated extract protein; total volume $2 \cdot 7 \mathrm{ml}$.

In each case curve (A) represents the control without substrate except in $(d)$ where substrate was present but coenzyme A was omitted. Oxidation of $\mathrm{NADH}_{2}$ was followed at $340 \mathrm{~nm}$ with a Unicam SP 800 spectrophotometer. All reactions at $25^{\circ}, \mathrm{pH} 7 \cdot 2$ under $\mathrm{N}_{2}$.

reflected by the acetate/glucose ratio and at alkaline $\mathrm{pH}$ values the thioclastic route was clearly predominant in Sarcina ventriculi (Table 4).

At controlled $\mathrm{pH}$ values of 6 and above the proportion of pyruvate metabolized via the thioclastic pathway remained constant throughout growth whereas at lower controlled $\mathrm{pH}$ values the acetate/glucose ratio fell as growth proceeded, e.g. at $\mathrm{pH} 4.7$ the ratios for the time periods noted were: 0 to $5 \mathrm{~h} ., 0.48 ; 5$ to $9 \mathrm{~h}$., 0.36 and 9 to I I h., 0.29 (the stationary phase was reached at $\mathrm{I} 5 \mathrm{~h}$.). The intracellular $\mathrm{pH}$ must therefore be significantly higher than $4 \cdot 7$ since the thioclastic activity of extracts is zero at this $\mathrm{pH}$.

\section{Molar growth yields for glucose}

Molar growth yields for glucose ( $Y_{\text {glucose }}=\mathrm{g}$. dry wt $/$ mole glucose) at various $\mathrm{pH}$ values were calculated from measurements made during the period of exponential growth of cultures at controlled constant $\mathrm{pH}$ (Table 5). $Y_{\text {ATP }}$ values (g. dry wt/mole ATP) were also 
computed on the assumption that Embden-Meyerhof glycolysis in conjunction with either pyruvate decarboxylase or the thioclastic enzyme yields respectively 2 and 3 moles ATP/mole glucose fermented. The acetate produced during growth was taken as an index of the thioclastic contribution to overall metabolism for these calculations; clearly this may introduce some experimental error. However, the $Y_{\mathrm{ATP}}$ values agree tolerably with the Bauchop \& Elsden (1960) value of 10.5 and those of subsequent workers (Payne, I970).

\section{DISCUSSION}

Our results show that two pathways of pyruvate metabolism are present in Sarcina ventriculi, a yeast-type thiamine pyrophosphate-dependent pyruvate decarboxylase producing acetaldehyde and $\mathrm{CO}_{2}$ and a clostridial-type thioclastic system yielding acetylphosphate, $\mathrm{CO}_{2}$ and $\mathrm{H}_{2}$. Molecular hydrogen is also produced from formate by a formate hydrogenlyase system in which ferredoxin is not required, showing the hydrogen-producing mechanism from formate to differ from that of the clostridial-type thioclastic reaction (Mortenson et al. 1962). The presence of formate hydrogenlyase activity in $\left(\mathrm{NH}_{4}\right)_{2} \mathrm{SO}_{4}$-fractionated extracts on the addition of ferredoxin probably indicates a lack of specificity for the electron carrier under these conditions and may not be of physiological significance.

Table 4. Effect of constant extracellular pH on acetate production from glucose during growth of Sarcina ventriculi in complex media

$\begin{array}{cc}\text { Molar ratio: } \\ \text { pH } & \begin{array}{c}\text { acetate produced } \\ \text { glucose utilized }\end{array} \\ 4.7 & 0.48,0.45^{*} \\ 5.0 & 0.50^{*} \\ 6.0 & 0.58,0.60 \\ 6.9 & 0.70 \\ 7.1 & 0.70 \\ 7.8 & 0.90\end{array}$

* The ratios recorded for $\mathrm{pH} 4.7$ and 5.0 refer to the early stages of growth; at these low pH values the ratios decreased as growth proceeded (see text) whereas at $\mathrm{pH} 6 \cdot 0$ and above the ratios remained constant throughout growth.

Table 5. Molar growth yields for Sarcina ventriculi on glucose

The $Y_{\text {glucose }}$ (g. dry wt/mole glucose) values were calculated from the exponential growth phase of bacteria grown at constant $\mathrm{pH}$. $Y_{\mathrm{ATP}}$ values were calculated as described in the text.

$\begin{array}{cccc}\begin{array}{c}\text { Controlled } \\ \text { growth pH }\end{array} & Y_{\text {glucose }} & Y_{\text {ATP }} & \begin{array}{c}\text { Percentage thio- } \\ \text { clastic reaction* }\end{array} \\ 4 \cdot 7 & 26 \cdot 6 & 10 \cdot 9 & 45 \cdot 0 \\ & 28 \cdot 5 & 11 \cdot 6 & 47 \cdot 5 \\ 5 \cdot 0 & 29 \cdot 5 & 12 \cdot 1 & 45 \cdot 4 \\ 6 \cdot 0 & 29 \cdot 2 & \text { II } \cdot 5 & 55 \cdot 8 \\ & 30 \cdot 6 & \text { I2.0 } & 49 \cdot 3 \\ 7 \cdot 1 & 33 \cdot 2 & \text { I2.6 } & 66 \cdot 0 \\ & 33 \cdot 0 & 12 \cdot 3 & 68 \cdot 1 \\ 7 \cdot 8 & 32 \cdot 8 & 12 \cdot 2 & 70 \cdot 2 \\ & 31 \cdot 9 & \text { II } \cdot 1 & 88 \cdot 6 \\ & 30 \cdot 2 & \text { I0.4 } & 90 \cdot 6 \\ & * \text { Based on acetate yield. }\end{array}$




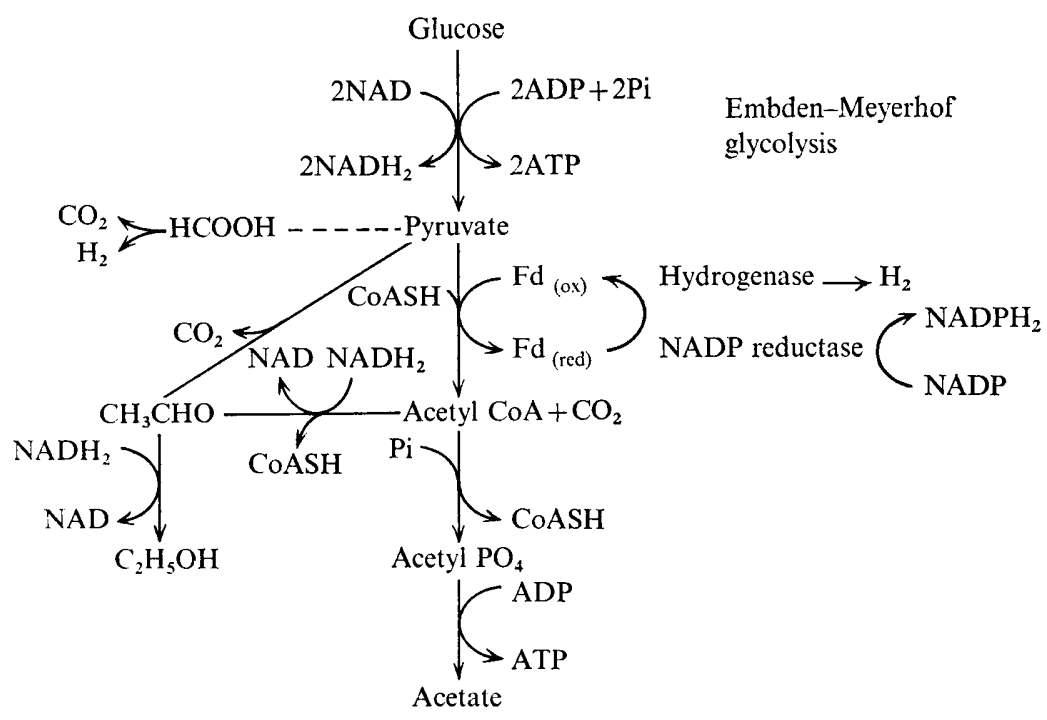

Fig. 8. Pyruvate metabolism in Sarcina ventriculi.

The presence in glucose-complex media-grown Sarcina ventriculi of formate hydrogenlyase, an enzyme system which is inducible in other bacteria, led to the assumption that formate probably arose from pyruvate via a coliform-type thioclastic (pyruvate-formate lyase) reaction, although direct evidence for this route was not adduced (Bauchop \& Dawes, I959). A study of the exchange reactions characteristic of the two known types of thioclastic enzyme was complicated by the presence of the formate hydrogenlyase system. Hespell, Joseph \& Mortlock (1969) studied the effect of coenzyme A and desulphocoenzyme A on both types of exchange reaction and we have performed similar experiments with extracts of S. ventriculi. $\mathrm{CO}_{2}$-pyruvate exchange was demonstrated, characteristic of the clostridial-type reaction. Formate-pyruvate exchange, although occurring to a slight extent, was sensitive to coenzyme A and desulphocoenzyme A unlike the coliform enzyme which is unaffected, and the observed incorporation was probably occurring via the formate hydrogenlyase system since ${ }^{14} \mathrm{C}$ incorporation from formate was absent in the presence of an unlabelled $\mathrm{CO}_{2}$ pool. The possibility that the apparent absence of the coliform-type enzyme might be due to its lability under the experimental conditions used cannot, of course, be completely excluded. Lindmark, Paolella \& Wood (1969) succeeded in purifying the exchange enzyme from Streptococcus faecalis by using a complex of $\mathrm{FeSO}_{4}$ and 2,3-dimercaptopropanol to protect the enzyme during purification, but this system did not protect the $S$. ventriculi enzyme, if present.

It thus appears that pyruvate is not the precursor of formate in Sarcina ventriculi. The possibility that the formate hydrogenlyase system was induced by adventitious formate in the complex growth medium was eliminated when the specific activity after growth in defined medium containing no formate was found similar to that after growth in complex medium. The system may therefore be constitutive in S. ventriculi. Jungermann, Kirchniawy \& Thauer (1970) demonstrated a formate hydrogenlyase system in Clostridium pasteurianum but were unable to detect pyruvate-formate lyase activity. They assigned a biosynthetic role to the formate hydrogenlyase system in what appears to be a situation analogous to that found with $S$. ventriculi. 
Hydrogen production is also linked to NADP reduction in Sarcina ventriculi and, as in some clostridia (Valentine, Brill \& Wolfe, 1962), is ferredoxin-dependent. From these findings the pathways of pyruvate metabolism in S. ventriculi may be charted (Fig. 8).

The divergent fermentation balances previously reported for Sarcina ventriculi (Kluyver, I93 I ; Milhaud et al. 1956; Canale-Parola, 1970) are explained by the relative importance of the two routes of pyruvate metabolism under the conditions employed. At $\mathrm{pH} 4 \cdot 7$ pyruvate decarboxylase and the thioclastic enzyme are of comparable importance but at alkaline $\mathrm{pH}$ the thioclastic enzyme predominates. The decreased activity of the thioclastic enzyme at pH 5 and below is further depressed as growth proceeds, most probably due to the acetate produced by this enzyme. As the $\mathrm{pH}$ falls acetate exists increasingly as the undissociated acid and this specie, rather than the acetate anion, enters the bacteria leading to high intracellular acetate concentrations. Higgins \& Johnson (1970) studied this effect with Escherichia coli and Aerobacter cloacae and concluded that the formation of acetate and formate from glucose was inhibited because of the mass action effect and close approach to equilibrium of the pyruvate-formate lyase reaction.

The molar growth yields for glucose at various controlled $\mathrm{pH}$ values reflect, in general, the effect of $\mathrm{pH}$ on the metabolism of pyruvate; the yield increases as the contribution of the thioclastic mechanism increases with higher $\mathrm{pH}$ due to the additional mole of ATP per mole glucose fermented derived from acetyl CoA via phosphotransacetylase and acetate kinase.

We are grateful to Mr D. A. Van Ham who carried out some exploratory experiments as part of a B.Sc. project and to Dr J. L. Peel for helpful discussion on the isolation of ferredoxin and for a generous gift of dried Peptostreptococcus elsdenii.

\section{REFERENCES}

Arbuthnott, J. P., Bauchop, T. \& Dawes, E. A. (1960). A clastic fission of pyruvic acid in Zymosarcina ventriculi. Biochemical Journal 76, I $2 \mathrm{P}$.

BARKer, S. A. \& Somers, P. J. (I966). A spectrophotometric method for the determination of formic acid in the periodate oxidation of carbohydrates. Carbohydrate Research 3, 220-224.

BAuchop, T. \& DAwES, E. A. (1959). Metabolism of pyruvic and formic acids by Zymosarcina ventriculi. Biochimica et biophysica acta 36, 294-296.

BAUCHOP, T. \& DAWEs, E. A. (1968). The metabolism of formic acid by Sarcina ventriculi. Journal of General Microbiology 52, 195-203.

BAUCHOP, T. \& ElSDEN, S. R. (1960). The growth of micro-organisms in relation to their energy supply. Journal of General Microbiology 23, 457-469.

Canale-Parola, E. (196I). Ph.D. Dissertation, University of rllinois, Urbana.

CANAle-PAROla, E. (1970). Biology of the sugar-fermenting sarcinae. Bacteriological Reviews $34,82$.

Canale-Parola, E. \& Wolfe, R. S. (1960). Studies on Sarcina ventriculi, II. Nutrition. Journal of Bacterio$\log y$ 79, 860-862.

Chase, J. F. A., Middleton, B. \& TubBs, P. K. (I966). A coenzyme A analogue, desulpho-CoA; preparation and effects on various enzymes. Biochemical and Biophysical Research Communications 23, $208-213$.

FrenCH, C.S. \& Milner, H.W. (1955). Disintegration of bacteria and small particles by high-pressure extrusion. In Methods in Enzymology, vol. 1, pp. 64-67. Edited by S. P. Colowick \& N. O. Kaplan. New York: Academic Press.

Friedemann, T. E. \& Haugen, G. E. (1943). Pyruvic acid. II. The determination of keto acids in blood and urine. Journal of Biological Chemistry 147, 4I 5-422.

Gornall, A. G., Bardawill, C. J. \& David, M. M. (1949). Determination of serum proteins by means of the biuret reaction. Journal of Biological Chemistry $177,75 \mathrm{I}-766$.

Hespell, R. B., Joseph, R. \& Mortlock, R. P. (1969). Requirement for coenzyme A in the phosphorociastic reaction of anaerobic bacteria. Journal of Bacteriology Ioo, 1328-1334.

Higgins, T. E. \& Johnson, M. J. (1970). Pathways of anaerobic acetate utilization in Escherichia coli and Aerobacter cloacae. Journal of Bacteriology 1or, 885-891. 
Hohorst, H. J. (1963). L (+) Lactate. Determination with lactic dehydrogenase and DPN. In Methods of Enzymatic Analysis, pp. 266-270. Edited by H. U. Bergmeyer. New York and London: Academic Press.

Jungermann, K., Kirchniawy, H. \& Thauer, R. K. (I970). Ferredoxin dependent $\mathrm{CO}_{2}$ reduction to formate in Clostridium pasteurianum. Biochemical and Biophysical Research Communications 4I, 682-689.

KING, T. E. \& Cheldelin, V. H. (I954). Pyruvic carboxylase of Acetobacter suboxydans. Journal of Biological Chemistry 208, 821-83I.

KLUYVER, A. J. (I93I). The Chemical Activities of Micro-organisms p. 39. London: University of London Press.

Lindmark, D. G., Paolella, P. \& Wood, N. P. (1969). The pyruvate-formate lyase system of Streptococcus faecalis. Journal of Biological Chemistry 244, 3605-36I 2.

LipmanN, F. \& Tuttle, L. C. (I945). A specific micromethod for the determination of acyl phosphates Journal of Biological Chemistry 159, $2 \mathrm{I}-28$.

MAyHEw, S. G. (1966). Studies on ferredoxin and rubredoxin. Ph.D. Thesis, University of Sheffield.

Milhaud, G., Aubert, J. P. \& VAN Niel, C. B. (1956). Etude de la glycolyse de Zymosarcina ventriculi. Annales de L'Institut Pasteur 9r, 363-368.

MoReY, A. V. \& JUNI, E. (1968). Studies on the nature of the binding of thiamine pyrophosphate to enzymes. Journal of Biological Chemistry 243, 3009-3019.

Mortenson, L. E., Valentine, R. C. \& Carnahan, J. E. (I962). An electron transport factor from Clostridium pasteurianum. Biochemical and Biophysical Research Communications 7, 448-452.

NeISH, A. C. (1952). Analytical methods for bacterial fermentations. National Research Council of Canada Report no. 46-8-3.

PAYNE, W. J. (1970). Energy yields and growth of heterotrophs. Annual Review of Microbiology 24, pp. I7-52.

SMIt, J. (1930). Die Gärungssarcine. Monographie Pflanzenforschung Heft 14. Jena: Gustav Fischer.

Stephenson, M. P. \& DaWes, E. A. (1970). The role of ferredoxin in formate metabolism of Sarcina ventriculi. Journal of General Microbiology, 6o, vi-vii.

VAlentine, R. C., Brill, W. J. \& Wolfe, R. S. (1962). Role of ferredoxin in pyridine nucleotide reduction. Proceedings of the National Academy of Sciences of the United States of America 48, I856-1860. 